\title{
Failure Mode and Effect Analysis a Tool for Reliability Evaluation: Review
}

\author{
Sunday A. Afolalu, Enesi Y. Salawu, Kehinde Oluyemi, Samuel U. Ayuba, Ikechi V. Ihebom and \\ Remilekun R. Elewa
}

\begin{abstract}
The purpose of safety designing is generally not on cost, but rather on saving life and nature, and consequently bargains just with specific risky system failure modes. High reliability levels are the consequence of good designing, scrupulousness and dependably never the aftereffect of redynamic failure management. Failure mode and effect analysis (FMEA) is a helpful technique analyzing engineering system reliability. The study focused on the use of FMEA technique to analyze the reliability of engineering equipment or components in selected areas such as: Wind Turbine component, Manufacturing Industries, Medical field and in evaluating the performances of Robots in different fields. The study showed the importance of FMEA as used widely in analyzing engineering equipment with regards to reliability.
\end{abstract}

Index Term-FMEA; Reliability; Failure Mode; Review; Engineering and Safety.

\section{INTRODUCTION}

The reliability of our engineering components is a key factor to take into consideration during process design. This is necessary to improve the efficient operation of the system while in operation. However, the importance of reliability depends on certain factors which invariably influence the engineering components. These factors include cost, safe design, system complexity, competitions etc. [1].

Reliability of an engineering component is therefore the probability that a component will function satisfactorily for at least a given period of time when used under stated conditions. It is an equipment design characteristic which determines the frequency with which a component is down for maintenance.

To reduce maintenance cost, there is need for effective asset management and evaluation hence the need for failure mode and effect analysis (FMEA) as a technique for reliability evaluation. For instance, [2] proposed a risk based maintenance model to improve the reliability of a process plant. The study employed the developed model to assess the reliability of the system's components as well as predicting failure in planning the maintenance schedule thereby increasing the systems' availability. The result of the developed model showed its effectiveness in identifying the critical equipment and systems' availability. A risk based maintenance technique has proved to be a cost effective tool in maintenance plan.

However, adopting FMEA technique to data from a catalytic process plant to analyze safety of personnel as well

Published on April 30, 2018.

Dr. Afolalu S, Adeniran works with the Covenant University Ota Nigeria (e-mail: sunday.afolalu@ covenantuniversity.edu.ng).

Engr. Salawu. E. Yusuf works with Covenant University Ota. Nigeria (e-mail:salawu.enesi@covenantuniversity.edu.ng). as impact of pollution on the environment showed that FMEA is effective in identifying the critical failures. Risk based maintenance technique is therefore very useful in improving the reliability of a high risk and technical facilities [3].

Failure mode and effect analysis technique was used investigate the root cause of failures in a water gasification plant. Cause and effect diagram, empirical failure mode and effects analysis and fuzzy failure mode and effect analysis were studied [4]. The result of the analysis revealed failures such as plugging of the plant, corrosion, reactor design and poor material selection and this generated great risk in the plant which include injury, odour and excessive noise.

Therefore, failure mode and effect analysis proved very useful in analyzing safety and sound operation of equipment. Reference [5] presents a study on how to reduce maintenance waste by using failure mode and effect analyses approach. The study presents a new improved model for evaluating the criticality waste management by modifying the FMEA. Further to this, consideration was given to analytical hierarchy process to assess the level of maintenance waste which paves way for the modification of FMEA. The result showed that FMEA was effective in waste assessment and elimination [6].

More so failure mode and effect analysis can be used to assess the criticality of failures in processes as well as in products during total quality management evaluation. For instance, [7] employed data envelopment technique as an FMEA to determine the maximum and minimum risks of failure mode and there mean value was taken to determine the risk value of failure modes. FMEA therefore is a good technique for determining potential failures. Having seen the general application of the FMEA as a reliability evaluation technique, the aim of this study is to evaluate the effectiveness of the application of failure mode and effect analysis in wind turbine performance, robotics performance and medical performance.

Furthermore, [8] applied the FMEA technique to develop an algorithm for reliability evaluation of electric motors which had power sources from a photovoltaic cell. The study focused on the failures which occur in the running of the motor parts such as the panel, the charger and the battery as well as the control module. Influences of the elements of the motor on its reliability were calculated and the predictions of the number of the occurrence of failures were equally recorded. The result of the algorithm was then used to determine the standard reliability indicators [9]. 


\section{FAILURE MODE AND EFFECT ANALYSIS IN WIND TURBINE RELIABILITY EVALUATION}

Failure mode and effects analysis can be used to evaluate the failure behavior of a floating offshore turbine [10]. The technique was used to assess connection between failure modes and effects on the failure probability of the entire system. A correlation coefficient was obtained from series of failure modes using the FMEA. The result showed that the quality of the floating foundation and the mooring system are demanding and failures on them can cause losses. However, analyzed data collected from a failed wind turbine tower which paved way for post disaster inspection into the root causes of the tower failure [11].

Wind speed data, structural tower analysis, construction records and documents as well as the tower design codes were collected and analyzed. The result of the analyses showed that the severity of the failures can be minimized or avoided in subsequent failures [12] employed a threeparameter Weibull failure rate function to analyze the reliability of wind turbines. The result of the analyses showed that the Weibull function gave a better accuracy on reliability growth of wind energy systems.

However, FMEA techniques use to analyze the real life data obtained from wind turbine systems and their assemblies [13]. 2MW Doubly Fed Induction Generator wind turbine was compared with a hypothetical wind turbine system using Brushless Dou-Fed Generator of the same rating. The result revealed the importance of FMEA in the reliability of wind turbine system.

More so [14] applied FMEA technique to the design of a 2MW R80 wind turbine in order to make comparison between the prospective reliabilities of the three versions. The essence was to limit the failure rate and improve on the reliability of turbine. The study focused on the integration of a Doubly Fed Induction Generator with a partially-rated Electrical Converter and Transformer and integration of innovative Hydraulic Converter coupled to an MV Synchronous Generator. The result showed that FMEA can be used for as a failure prediction tool.

Furthermore, development of a mathematical model for risk and failure mode analysis has eliminated the major problems of that are associated with wind turbines that are used in wind farms. Hence power production losses, costs of logistics and transportation have been reduced drastically [15]. However, adopting the FMEA technique to assess the reliability characteristics of a 5MW turbine has improved the efficiency of the turbine as a result of proper investigation into the failed part using finite element analysis (FEA).

\section{FAILURE MOdE AND EFFECT ANALYSIS (FMEA) FoR RELIABILITY EVALUATION IN THE MANUFACTURING INDUSTRY}

Equipment unavailability and process variations can be reduced drastically using reliability evaluation technique. For instance, [16] adopted failure mode and effect analysis technique to develop a maintenance model for effective maintenance foundry plant. The maintenance history data of the foundry equipment was collected and analyzed to predict the preventive maintenance of the equipment in order to improve the reliability of the equipment. The result revealed that FMEA technique showed the various failures that were associated with the equipment.

However, MEA approach is us to analyze and predict failures in a food processing plant [17]. The study focused on the characteristics and interactions of the ingredient or the process of which the equipment depends. The study further optimized the potentials of the FMEA technique using the pare to diagram. Furthermore, to have an effective lean production system in an organization, FMEA play a key role especially in reducing the machine downtime, improving reliability and efficiency. Further to these cost reduction, higher quality would be achieved successfully [18].

However, process failure mode and effect analysis has a major drawback especially when integrated with lean production in an automotive industry. Study has shown that development of an algorithm into the FMEA gave a better performance as it is evident in the reduction of failure occurrence in the automotive industry [19]. The application of FMEA generally cannot be overemphasized as it was found useful in improving the reliability of plastic welding equipment used in blood bags production. FMEA was used to evaluate different parameters such as Severity values, Occurrence number and Detection and Risk Priority Number.

The application of this technique had drastically reduced loss of production hours[20]. However, quality assessment of product during manufacturing is highly essential. Application of FMEA is of great relevance in removing potential errors during manufacturing. It is a standard procedure in product design and operations management for analysis of potential failure modes in a system [21].

Operational failure and dangers associated with crankcase explosion and wear of the tools in a marine ship, [21]-[22] adopted FMEA technique to improve the reliability of the ship as well as operational safety concepts on board ship. The FMEA approach reduced the probability of the crankcase explosion as well as improving the reliability of the onboard ship.

According to [23] assessing the cost of risk is important in planning production processes. A cost-based FMEA was to predict the cost of failure of an electronic system which yielded positive forecasts of the risk associated with a leadfree control plan for products operating in different risk scenarios [24].

\section{FAILURE MODE AND EFFECTS ANALYSIS FOR RELIABILITY IMPROVEMENTS IN MEDICAL}

Possible failures from medical equipment can lead to great loss in the life of patients. Studies have shown that identifying these potential failures from the systems could reduce or eliminate the rate of losses of life due to faulty equipment as well as improving the safety of the system. For instance, [25]-[27] applied the failure mode and effect analysis technique to assess the potential hazards in a health information system. The study however focused on the possible failure mode which was eventually identified by the technique. 
The result of the assessment showed that FMEA is a riskassessment technique for Maternal and Infant Network.

According to [28] in order to understand and assess the risk associated with medical equipment, it important to use FMEA approach to study these potential dangers faced by medical infrastructures as well as reduce the potential failures.

Further to this risk assessment established that medical products development processes can be monitored using the traditional FMEA and the Fuzzy FMEA. The two techniques were used to assess the risk associated with each development phase of a dental product manufacturing based on the source of occurrence.

A comparative study of the both wear techniques was carried out and it was revealed that the fuzzy approach avoids the duplication of the Risk Priority Number as well as good and logical results were obtained which might affect the reliability of the system employed the FMEA approach to improve the reliability of the Intensive Care Unit of a hospital. Quantitative data analysis was carried out based on failures' Risk Priority Number at the base of Failure Mode and Effects Analysis technique.

The result showed that 378 potential failure modes from 180 ICU activities in hospital A and 184 potential failures from 99 ICU activities in hospital were identified and evaluated. Application of FMEA on the activities of the hospitals had improved process reliability.

However, vulnerabilities that are related to communication and handover in emergency care pathways can be avoided by integrating a Functional Resonance Analysis Method with FMEA. FMEA is therefore useful as an appropriate tool used in health care for solving failure problem.

\section{ApPlication of FMEA in EVAluating the RELIABILITY OF ROBOT}

Robot application in various fields of human endeavors had enhanced the productivity especially in the manufacturing industries. Many activities performed by human have been automated using robots thereby making the job faster and accurate. However, the reliability assessment of these robots is essential for continuous improvement in their performance [27]. For instance, improved on the functionalities of revolute and prismatic robots. The study focused on improving the design of the robots by correcting the design and effecting the changes on the manufactured robots having checked the performance indices.

However, conceptual planning before embarking on the development of a product is highly essential using a technique known as cost-based FMEA. This approach could be technically applied to estimate the cost of conceptual design during the product design phase be estimating the cost of risks integrated with the studied process plan and to assess the failure modes due to the production processes as well as estimating the cost of failure. [25].

More so, a technique known as functional failure modes cause-consequence logic which had its application in mobile robot. The study focused on using this technique to reduce the failures, hazards which users usually experience. The result showed that the entropy based technique was comprehensive it provided an alternative and efficient method to analyze a larger class of complex machine reliability issues [29].

\section{SUMMARY}

Reliability engineering deals with quality centers around expenses of failure caused by system downtime, cost of extras, repair gear, work force and cost of guarantee claims. It is therefore very essential to assess or measure the reliability of engineering component in order to reduce failures as well as the associated cost. The study focused on the use of FMEA on reliability improvements in Wind Turbine equipment, Manufacturing systems, Medical equipment and as well as in Robots. FMEA therefore is a useful tool in reliability analysis engineering systems.

\section{ACKNOWLEDGMENT}

We acknowledge the financial support offered by Covenant University in actualization of this research work for publication.

\section{REFERENCES}

[1] A. Hoseynabadi, P. J Oraee, and P. J. Tavner. 2010. "Failure Modes and Effects Analysis (FMEA) for Wind lines." International Journal of Electrical Power and Energy Systems 2010., 32(7):817-24.

[2] S. A Afolalu, S.B Adejuyigbe, O.R Adetunji. Impacts of temperature and holding time on wear of high speed steel cutting tools. International Journal of Scientific \& engineering Research, Volume 6 , Issue 5, 2015., 905-909'

[3] S. A. Afolalu, S.B., Adejuyigbe, O.R Adetunji. and O.I Olusola. Production of Cutting Tools from Recycled Steel with Palm Kernel Shell as Carbon Additives. International Journal of Innovation and Applied Studies, 12(1), 2015 p.110.

[4] I. Veza, B. Bilic, "An Integrated Lean Approach to Failure Mode and Effect Analysis (PFMEA): A Case Study from Automotive Industry.' Advances in Production Engineering \& Management, 2016. 11:35565.

[5] Chin, Ying-ming Wang, Gary Ka, Kwai Poon, and Jian-bo Yang. "Failure Mode and Effects Analysis by Data Envelopment Analysis." Decision Support Systems 48(1): 2009. 246-56.

[6] Jui-sheng and Wan-ting Tu, "Failure Analysis and Risk Management of a Collapsed Large Wind Turbine Tower." Engineering Failure Analysis 2011. 18(1):295-313.

[7] K. Kadir and Metin Celik. "Application of Failure Modes and Effects Analysis to Main Engine Crankcase Explosion Failure On-board Ship." Safety Science 2013. 51(1):6-10.

[8] E.Y. Salawu., I.P Okokpujie., S.A Afolalu, Ajayi, O.O. J. Azeta 2018. Investigation of Production Output for Improvement. International Journal of Mechanical and Production Engineering Research and Development, 8(1), 2018, pp.915-922

[9] G. H. Simon Watson, Peter Tavner, and Jiangping Xiang. "Reliability Analysis for Wind Turbines with Incomplete Failure Data Collected from after the Date of Installation." Reliability Engineering and System Safety 2009. 94:1057-63.

[10] H. A. Ali Siadat, Jean-yves Dantan, and Patrick Martin, "Robotics and Computer-Integrated Manufacturing Conceptual Process Planning - an Improvement Approach Using QFD,FMEA, and ABC Methods.' Robotics and Computer Integrated Manufacturing 2010. 26(4):392401.

[11] D. Imran, V. Seppo, B., Pi A. K. Verma. 2014. "Functional Failure Modes Cause-Consequence Logic Suited for Mobile Robots Used at Scientific Facilities.” Reliability Engineering and System Safety 2014 129:10-18.

[12] O., Issn., P. Issn, and Mehta Gauravkumar Bharatbhai.. "Failure Mode and Effect Analysis of Repower 5M Wind Turbine." International Journal of Advance Research in Engineering, Science\& Technology 2015. 2(5):1-8. 
[13] J. Kang, S. Liping, S. Hai, and W. Chunlin Wu. "Risk Assessment of Floating Off Shore Wind Turbine Based on Correlation-." Ocean Engineering 2017. 017129(154):382-88.

[14] B. Karatop and S. Mehmet. 2017. "The Risk Analysis by Failure Mode and Effect Analysis (FMEA) and Fuzzy-FMEA of Supercritical Water Gasi Fi Cation System Used in the Sewage Sludge Treatment.' Journal of Environmental and Chemical Engineering 5:1261-68.

[15] S. Kiran., K.P Prajeeth, B. Sreejith, and M. Muralidharan. 2016. "Reliability Evaluation and Risk Based Maintenance in a Process Plant." Procedia Technology 24:576-83.

[16] M.S Kirkire, S. R. Santosh and R.J Jagdish. "Risk Management in Medical Product Development Process Using Traditional FMEA and Fuzzy Linguistic Approach: A Case Study." Journal of Industrial Engineering International 2012 11(4):595-611.

[17] K. P, Faisal et al. "Application of Fmea Method in a Manufacturing Organization Focused on Quality." International Journal of Engineering and Innovative Technology 2015 4(7):64-70.

[18] E. Lillie, S. Peter S, and H. David, "Assessing the Value of a LeadFree Solder Control Plan Using Cost-Based FMEA.' Microelectronics Reliability 55(6):969-79.

[19] Y. N. Maddahi,. H. Sepehri,. Ghorabi, and A. Maddahi. 2010. "Testing Robotic Manipulators: Improvement and Experience." International Journal of Systems Applications, Engineering and Development 4(2).

[20] S. Mahmood, S.A Ami, 2014. "Application of FMEA and AHP in Lean Maintenance." International Journal of Modern Engineering Science (September):61-73.

[21] R.A. Munteanu., D. Iudean, V. Zaharia, C. Muresan, and T. Cretu. Implementing a Failure Mode and Effect Analysis for Small and Medium Electric Motors Powered from Photovoltaic Panels. IFAC. 2013

[22] B. O. Orisanmi, S.A Afolalu, O.R Adetunji, O. R., Salawu, E. Y., \& Okokpujie, I. P. (2017). Cost of Corrosion of Metallic Products in Federal University of Agriculture, Abeokuta. International Journal of Applied Engineering Research, 12(24), 14141-14147

[23] S. Pandey and Z. Xufang. "System Reliability Analysis of the Robotic Manipulator with Random Joint Clearances." Mechanism and Machine Theory, 2012., 58:137-52.

[24] M. Shafiee and D. Fateme Dinmohammadi. "An FMEA-Based Risk Assessment Approach for Wind Turbine Systems: A Comparative
Study of Onshore and Offshore. Energy" www.mdpi.com/journal/energies, 2013, 619-42.

[25] S.Sujan,r and F. Massimo. 2012. "Combining Failure Mode and Functional Resonance Analyses in Healthcare Settings." www.dblue.it, 2012, 364-75.

[26] G. Indra, and T. Stenly. 2015. "Modified Failure Mode and Effect Analysis (FMEA) Model for Accessing the Risk of Maintenance Waste." Procedia Manufacturing 4(Iess):23-29.

[27] A Tavner, H. Higgins, H. Arabian, H. Long, and Y. Feng. 2010 "Using an FMEA Method to Compare Prospective Wind Turbine Design Reliabilities." European Wind Energy Conference (EWEC 2010) (Ewec):1-10.

[28] U. Saluja, N. Barshah. 2012. "Information Risk Management Qualitative or Quantitative? Cross Industry Lessons from Medical and Financial Fields." Systematics, Cybernetics and Informatics 2012. 10(3):54-59.

[29] S. A. Afolalu, E.Y Salawu, I.P. Okokpujie, A. A. Abioye., O.P. Abioye, M. Udo \& O. M. Ikumapayi, Experimental Analysis of the Wear Properties of Carburized HSS (ASTM A600) Cutting Tool. International. Journal of Applied Engineering Research, 12(19), 2017 8995-9003.

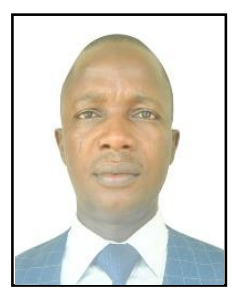

Dr Afolalu S. Adeniran is a lecturer and researcher in the department of Mechanical Engineering, Covenant University, Ota. Nigeria. He has published several articles and conference papers.

Engr Enesi Y. Salawu is a lecturer and he is currently pursuing his $\mathrm{PhD}$ in the department of Mechanical Engineering, Ota. Nigeria.

Remilekun R. Elewa, Samuel.U Ayuba, Ikechi V. Ihebom and Kehinde Oluyemi are post graduate students of Mechanical Engineering Students of Covenant University, Ota. Nigeria 